\title{
Decision Support System Pemilihan Karyawan Berprestasi Dengan Pendekatan Analisa Gap Profile matching Di Kantor Perwakilan Bank Indonesia Provinsi Aceh
}

\author{
Munawir $^{1}$, Ardiansyah $^{2}$ \\ 1 AMIK Indonesia \\ 2 Bank Indonesia
}

article info

\section{Article history:}

Received 6 December 2016

Received in revised form

2 February 2017

Accepted 27 Maret 2017

Available online 7 April 2017

\section{Keywords:}

Decision Support

System, Employee

Achievement,

Profile Profile

matching

\begin{abstract}
a bstract
One method of decision support system is the method of profile matching, this study builds a decision support system in the selection of outstanding employees at the Bank Indonesia Regional Office of Aceh Province which is expected to assist decision makers in deciding the best alternatives in the selection of outstanding employees. By using profile matching that can process and compare the actual data value of a profile to be assessed with the expected profile value, so it can know the difference of competence (also called gap), the smaller the resulting gap the greater the value of value which means have the opportunity greater to be recommended as an outstanding employee. Decision Support System (DSS) can take into account all the criteria that support decision-making to help speed up and simplify the decision-making process. The results of this study will generate a ranking ranking of employees and this application can assist decision makers (decission maker) in choosing an alternative employee who excel.
\end{abstract}

a bstrak

Salah satu metode sistem pendukung keputusan adalah metode profile matching, penelitian ini membangun sebuah sistem pendukung keputusan dalam pemilihan karyawan berprestasi di Kantor Perwakilan Bank Indonesia Provinsi Aceh yang diharapkan dapat membantu para pembuat keputusan dalam memutuskan alternatifalternatif terbaik dalam pemilihan karyawan berprestasi. Dengan menggunakan profile matching yang dapat memproses dan membandingkan antara nilai data aktual dari suatu profil yang akan dinilai dengan nilai profil yang diharapkan, sehingga dapat diketahui perbedaan kompetensinya (disebut juga gap), semakin kecil gap yang dihasilkan maka bobot nilainya semakin besar yang berarti memiliki peluang lebih besar untuk direkomendasikan sebagai karyawan berprestasi. Sistem Pendukung Keputusan (SPK) ini dapat memperhitungkan segala kriteria yang mendukung pengambilan keputusan guna membantu mempercepat dan mempermudah proses pengambilan keputusan. Hasil penelitian ini akan menghasilkan urutan rangking dari karyawan dan aplikasi ini dapat membantu pengambil keputusan (decission maker) dalam memilih alternatif karyawan yang berprestasi. 


\section{Latar Belakang}

Sumber daya manusia merupakan salah satu faktor yang menentukan efektifitas dan produktifitas suatu organisasi, Keberhasilan semua jenis organisasi pada dasarnya bergantung pada keahlian dan kemampuan komunitas para karyawan yang membentuknya. Kunci kelangsungan hidup organisasi terletak pada efektifitas organisasi dalam membina dan memanfaatkan keahlian karyawan dengan berusaha meminimalkan kelemahan mereka. Efektifitas organisasional bergantung pada efektifitas SDM-nya. Eksistensi seorang karyawan dalam menjalankan tugasnya sangat mendukung suatu pencapaian perusahaan. Sumber daya manusia yang handal mampu menolong organisasi menghadapi tantangan persaingan global. Karyawan adalah pelaksana utama setiap fungsi organisasi terhadap sarana, prasarana, dan infrastruktur yang ada. (Syamsul Rizal, 2017:40).

Lembaga perbankan merupakan tempat untuk melakukan transaksi keuangan, baik dari masyarakat dalam bentuk tabungan maupun dari pihak bank berupa kredit dan jasa pelayanan perbankan lainnya. Di dalam pekerjaannya, karyawan bank dapat mengalami stres kerja. Efek psikologis yang paling sederhana dan jelas dari stres kerja adalah turunnya produktivitas kerja. Produktivitas kerja timbul sebagai respon efektif atau emosional terhadap berbagai aspek pekerjaan. Ketidakpuasan kerja akan menimbulkan sikap acuh tak acuh karyawan bank terhadap apa yang terjadi pada lembaga perbankan tersebut. Oleh karena itu, lembaga perbankan perlu memperhatikan sumbersumber stres kerja sehingga stres kerja karyawan bank Syariah dapat dihindarkan dan produktivitas kerja dapat ditingkatkan. (Ijal Fahmi, 2017:60). Hal lain juga disampaikan Badaruddin (2017:33) rangsangan lingkungan mengindikasikan bahwa rangsangan lingkungan mempunyai pengaruh dengan emosi positif.

Menyadari bahwa memberikan apresiasi kepada karyawan yang berprestasi sangat penting untuk mendukung dalam peningkatan prestasi kerja karyawan, beberapa di antaranya melakukan program pemilihan karyawan berprestasi serta diberikan kesempatan untuk meningkatkan kapasitas sumber daya manusianya melalui prestasi seorang karyawan.

Kantor Perwakilan Bank Indonesia Provinsi Aceh selalu memberikan kesempatan kepada para karyawan dalam mengikuti kegiatan karyawan berprestasi yang diadakan setiap tahunnya. Namun, mendapatkan program karyawan berprestasi tersebut tidak semudah yang dibayangkan, karena semua karyawan yang dinilai wajib memenuhi beberapa kriteria dan persyaratan.

Banyaknya karyawan yang bekerja dengan berbagai bidang pekerjaan, tentu akan sangat memakan waktu yang lama jika prosesnya masih dilakukan secara manual. Selain itu memungkinkan terjadinya buman error dalam proses pengolahan data yang digunakan dalam proses pemilihan. Untuk itu diperlukan suatu Sistem Pendukung Keputusan (SPK) yang dapat memperhitungkan segala kriteria yang mendukung pengambilan keputusan guna membantu, mempercepat dan mempermudah proses pengambilan keputusan.

Salah satu metode sistem pendukung keputusan adalah metode profile matching. Metode ini cukup efektif dalam menyederhanakan dan mempercepat proses pengambilan keputusan dengan memecahkan persoalan tersebut ke dalam bagian-bagiannya. Dengan metode profile matching ini peneliti membuat sebuah sistem yang berjudul "Decision Support System Pemilihan Karyawan Berprestasi dengan Pendekatan Analisa Gap Profile matching di Kantor Perwakilan Bank Indonesia Provinsi Aceh" yang diharapkan dapat membantu para pembuat keputusan dalam memutuskan alternatif-alternatif terbaik dalam pemilihan karyawan berprestasi.

\section{Metode Penelitian}

\subsection{Profile matching}

Model Sistem Pendukung Keputusan untuk jabatan tertentu berdasarkan ketersediaan posisi jabatan yang dibutuhkan atau kosongnya jabatan yang ada, dibuat dalam tiga aspek, yaitu aspek intelektual, 
aspek sikap dan aspek perilaku. Dimana masingmasing unsur aspek tersebut memiliki beberapa elemen penilaian yang akan menetukan hasil akhir sistem pendukung keputusan yang akan digunakan oleh pengguna (manajerial) dalam menentukan suatu keputusan. (Amalia dkk, 2009:60).

Berdasarkan identifikasi masalah yang ada dan identifikasi kriteria nilai yang ditetapkan maka seleksi pemodelan yang dipakai dalam kasus kali ini lebih mendekati melalui pemodelan dengan algoritma ranking yang dalam penyelesaian masalahnya menggunakan profile matching, profile matching merupakan suatu proses dalam manajemen SDM dimana proses terlebih dahulu ditentukan nilai kemampuan yang diperlukan oleh suatu jabatan, dan nilai kemampuan tersebut harus dapat dipenuhi tingkat kecocokan oleh kandidat karyawan. Secara garis besar dapat dijelaskan proses ini membandingkan antara nilai kemampuan kandidat karyawan kedalam nilai kemampuan jabatan sehingga dapat diketahui perbedaan kemampuannya yang disebut gap (Kusrini, A.M., 2004:2).

\subsection{Analisis Penyelesaian}

Berikut adalah beberapa tahapan dan perumusan perhitungan dengan metode profile matching (Kusrini, A.M., 2004:2) :

a. Pemetaan Gap Kompetensi

Yang dimaksud dengan Gap disini adalah selisih /beda antara profil karyawan dengan profil standar yang diharapkan atau dapat ditunjukkan pada rumus di bawah ini :

\section{Gap $=$ Profil Karyawan - Profil standar}

Profil karyawan yaitu nilai-nilai yang diperoleh dari karyawan sedangkan profil standar yaitu nilai standar yang ditentukan terlebih dahulu. Setelah diperoleh gap pada masing-masing karyawan, setiap profil karyawan diberi bobot nilai dengan patokan.

b. Pembobotan

Pada tahap ini, akan ditentukan bobot nilai masing-masing aspek dengan menggunakan bobot nilai yang telah ditentukan bagi masingmasing aspek itu sendiri. Dalam penentuan peringkat pada aspek kapasitas intelektual, sikap kerja dan perilaku untuk karyawan yang sama pada setiap gap, diberikan bobot nilai sesuai dengan tabel berikut :

Tabel 1. Bobot Nilai Gap

\begin{tabular}{|c|c|c|}
\hline No & Selisih Gap & Bobot Nilai \\
\hline 1 & 0 & 6 \\
\hline 2 & 1 & 5.5 \\
\hline 3 & -1 & 5 \\
\hline 4 & 2 & 4.5 \\
\hline 5 & -2 & 4 \\
\hline 6 & 3 & 3.5 \\
\hline 7 & -3 & 3 \\
\hline 8 & 4 & 2.5 \\
\hline 9 & -4 & 2 \\
\hline 10 & 5 & 1.5 \\
\hline 11 & -5 & 1 \\
\hline
\end{tabular}

c. Perhitungan dan Pengelompokan Core dan Secondary factor

Setelah menentukan bobot nilai gap untuk ketiga aspek yang dibutuhkan, kemudian tiap aspek dikelompokan lagi menjadi 2 kelompok yaitu core factor dan secondary factor.

- Core factor (Faktor Utama)

Core factor merupakan aspek (kompetensi) yang paling menonjol/ paling dibutuhkan oleh suatu jabatan yang diperkirakan dapat menghasilkan kinerja optimal. Untuk menghitung Core factor digunakan rumus :

$$
\mathrm{NCF}=\frac{\sum N C}{\sum I C}
$$

Keterangan :

$\begin{array}{ll}\text { NCF } & \text { : Nilai rata-rata Core factor } \\ \text { NC } & \text { : Jumlah total nilai Core factor } \\ \text { IC } & \text { : Jumlah item Core factor }\end{array}$

- Secondary factor (Faktor Pendukung)

Secondary factor adalah item-item selain aspek yang ada pada Core factor. Untuk menghitung secondary factor digunakan rumus :

$$
N S F=\frac{\sum N S}{\sum I S}
$$

Keterangan :

$\begin{array}{ll}\text { NSF } & \text { : Nilai rata-rata secondary factor } \\ \text { NS } & \text { : Jumlah total nilai secondary factor } \\ \text { IS } & \text { : Jumlah item secondary factor }\end{array}$

Rumus diatas adalah rumus untuk menghitung Core factor dan secondary factor dari aspek kapasitas intelektual. Rumus diatas juga digunakan untuk menghitung Core factor dan secondary factor dari aspek sikap kerja dan perilaku. 


\subsection{Penilaian Nilai Total}

Dari perhitungan core factor dan secondary factor dari tiap-tiap aspek, kemudian dihitung nilai total dari tiap-tiap aspek yang diperkirakan berpengaruh pada kinerja tiap-tiap profile. Untuk menghitung nilai total dari masing-masing aspek, digunakan rumus :

$$
\mathrm{N}=\mathrm{X} \% \mathrm{NCF}+\mathrm{X} \% \mathrm{NSF}
$$

Keterangan :

$\begin{array}{ll}\mathrm{N} & : \text { Nilai total tiap aspek } \\ \mathrm{X} \% & \text { : Nilai persen yang diinputkan } \\ \mathrm{NCF} & \text { : Nilai rata-rata Core factor } \\ \mathrm{NSF} & : \text { Nilai rata-rata Secondary factor }\end{array}$

2.4. Perhitungan Rangking

Hasil akhir dari proses profile matching adalah rangking dari karyawan yang diajukan untuk penilaian karyawan berprestasi. Penentuan ranking mengacu pada hasil perhitungan yang ditujukan pada rumus dibawah ini :

\section{Ranking $=\mathrm{X} \% \mathrm{~N} 1+\mathrm{X} \% \mathrm{~N} 2+\mathrm{X} \% \mathrm{~N} 3$}

Keterangan :

$\mathrm{X} \% \quad$ : Nilai persen yang diinputkan

N1, N2, N3 : Nilai aspek yang sudah dihitung total

Pada penelitian ini, penentuan kriteria yang akan digunakan ditentukan oleh Pimpinan (Decision Maker) yang disesuaikan dengan aturan-aturan yang ada pada objek penelitian, serta didasarkan pada peraturan terkait pemilihan karyawan berprestasi.

\subsection{Desain Penelirian}

Penelitian ini menggunakan metode penelitian kualitatif bersifat deskriptif atau descriptive research. Suryabrata (2012:75) menjelaskan bahwa, "Secara harfiah, penelitian deskriptif adalah penelitian yang bertujuan untuk membuat pencandraan secara sistematis, faktual dan akurat mengenai fakta-fakta dan sifat-sifat populasi pada daerah tertentu". Data yang dikumpulkan dalam penelitian deskriptif adalah berupa kata-kata, gambar, dan bukan angkaangka. Hal ini disebabkan oleh adanya penerapan metode kualitatif. Dengan demikian, laporan penelitian ini akan berisi kutipan-kutipan data untuk memberi gambaran penyajian laporan tersebut. Data tersebut mungkin berasal dari naskah wawancara, catatan lapangan, foto, videotape, dokumen pribadi, catatan atau memo, dan dokumen resmi lainnya. (Moleong, 2006).
Penelitian kualitatif bersifat deskriptif artinya hasil eksplorasi atas subjek penelitian atau para partisipan melalui pengamatan dengan semua variannya, dan wawancara mendalam serta Focus Groups Discussion (FGD) harus dideskripsikan dalam catatan kualitatif yang terdiri dari catatan lapangan, catatan wawancara, catatan pribadi, catatan metodologis, dan catatan teoretis. (Putra, 2012:71). Deskripsi mengharuskan peneliti menggambarkan secara rinci, lengkap dan mendalam hasil wawancara, pengamatan dan FGD. FGD adalah diskusi yang dilakukan dalam kelompok dengan topik-topik tertentu yang dapat membantu memperdalam sekaligus memeriksa data.

Berdasarkan pendapat di atas, maka penelitian kualitatif bersifat deskriptif yang dimaksud dalam penelitian ini adalah suatu metode penelitian yang menganalisis dan memecahkan masalah berdasarkan penelitian di lapangan dan beberapa sumber data yang berkaitan dengan topik pembahasan. Kemudian mendeskripsikan dan menjelaskan fenomena hasil temuan di lapangan secara sistematis dan akurat.

\subsection{Sumber dan Teknik Pengumpulan Data}

Sumber dan teknik pengumpulan data merupakan bagian integral dari desain penelitian. Tersedia berbagai teknik pengumpulan data dengan segala kelebihan dan kekurangannya. Secara garis besar sumber dan teknik pengumpulan data yang peneliti gunakan sebagai berikut :

a. Sumber Data Primer

Menurut Sarwono (2006:209) definisi data primer adalah data yang diperoleh melalui pertanyaan tertulis dengan menggunakan kuesioner atau lisan dengan metode wawancara.

b. Sumber Data Sekunder

Menurut Sarwono (2006:209) definisi data sekunder adalah data yang bukan dari sumber pertama sebagai sarana untuk memperoleh data atau informasi untuk menjawab masalah yang diteliti. Data Sekunder yang diperoleh peneliti berdasarkan dokumentasi-dokumentasi dari beberapa buku.

2.7. Teknik Pengumpulan Data

a. Observasi

Observasi adalah pengamatan secara langsung 
ke lapangan untuk melihat lebih dekat objek yang akan diteliti. Observasi menurut Patton adalah "Deskripsi kerja lapangan kegiatan, perilaku, tindakan, percakapan, interaksi interpersonal, organisasi atau proses masyarakat, atau aspek lain dari pengalaman manusia yang dapat diamati. Data terdiri dari catatan lapangan, melalui deskripsi rinci termasuk konteks dimana pengamatan dilakukan" (Emzir, 2012:65). Jenis observasi yang dilakukan dalam penelitian ini adalah observasi non partisipan.

b. Wawancara

Wawancara merupakan salah satu teknik pengumpulan data dengan melakukan tanya jawab bersama narasumber. Wawancara ini dilakukan apabila ingin mendapat informasi lebih mendalam tentang sesuatu yang akan diteliti. Menurut Patton wawancara adalah "Pertanyaaan terbuka dan teliti hasil tanggapan mendalam tentang pengalaman, persepsi, pendapat, perasaan, dan pengetahuan orang. Data terdiri dari kutipan yang sama persis dengan konteks yang cukup untuk dapat diinterpretasi”. (Emzir, 2012:65). Yang menjadi sasaran wawancara dalam penelitian ini adalah Karyawan Kantor Perwakilan Bank Indonesia Provinsi Aceh.

2.8. Kebutuhan Perangkat Lunak

Proses pengumpulan kebutuhan diintensifkan dan difokuskan pada perangkat lunak. Untuk memahami sifat program yang dibangun, perekayasa perangkat lunak (analisis) harus memahami domain informasi, tingkah laku untuk kerja, dan antarmuka (interface) yang diperlukan. Dalam merancang suatu perangkat lunak, perlu memperhatikan kebutuhan yang akan digunakan dalam perancangan aplikasi sebagai berikut :

a. Hardware

Spesifikasi kebutuhan perangkat keras dalam penelitian ini adalah sebagai berikut :

- Laptop/PC

- Processor minimum Intel Pentium IV

- RAM minimum $512 \mathrm{MB}$

b. Software

Spesifikasi kebutuhan perangkat lunak dalam penelitian ini adalah sebagai berikut :

- Framework 3.5.
- VB.NET, sebagai bahasa pemrograman untuk membuat perangkat lunak.

- Ms. Acces, sebagai software database.

\section{Pembahasan}

3.1. Kriteria Penentuan Karyawan Prestasi

Untuk mendapatkan nilai dari karyawan, karyawan yang terpilih tentu harus sesuai dengan kriteria yang sudah ditentukan. Dari kriteria tersebut, tentu mempunyai nilai interval sebagai bahan untuk penentuan keputusan. Kriteria tersebut adalah sebagai berikut :

Tabel 2. Tabel Kriteria

\begin{tabular}{|l|l|l|l|}
\hline No & \multicolumn{1}{|c|}{ Kriteria } & \multicolumn{2}{|c|}{ Nilai } \\
\hline 1 & Disiplin & Kurang & 1 \\
& & Cukup & 2 \\
& & Baik & 3 \\
& & Sangat Baik & 4 \\
\hline 2 & Kerjasama & Kurang & 1 \\
& & Cukup & 2 \\
& & Baik & 3 \\
& & Sangat Baik & 4 \\
\hline 3 & Prestasi Kerja & Kurang & 1 \\
& & Cukup & 2 \\
& & Baik & 3 \\
& & Sangat Baik & 4 \\
\hline 4 & Masa Kerja & $>$ 1 Tahun & 0 \\
& & $>$ 2 Tahun & 1 \\
& & $>4$ Tahun & 2 \\
& & $>$ 5 Tahun & 3 \\
& & $>6$ Tahun & 4 \\
\hline
\end{tabular}

3.2. Diagram Konteks

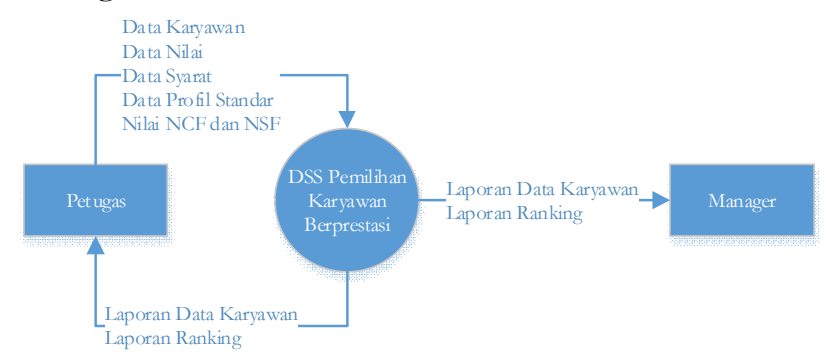

Gambar 1. Diagram Konteks 
3.3. Data Flow Diagram

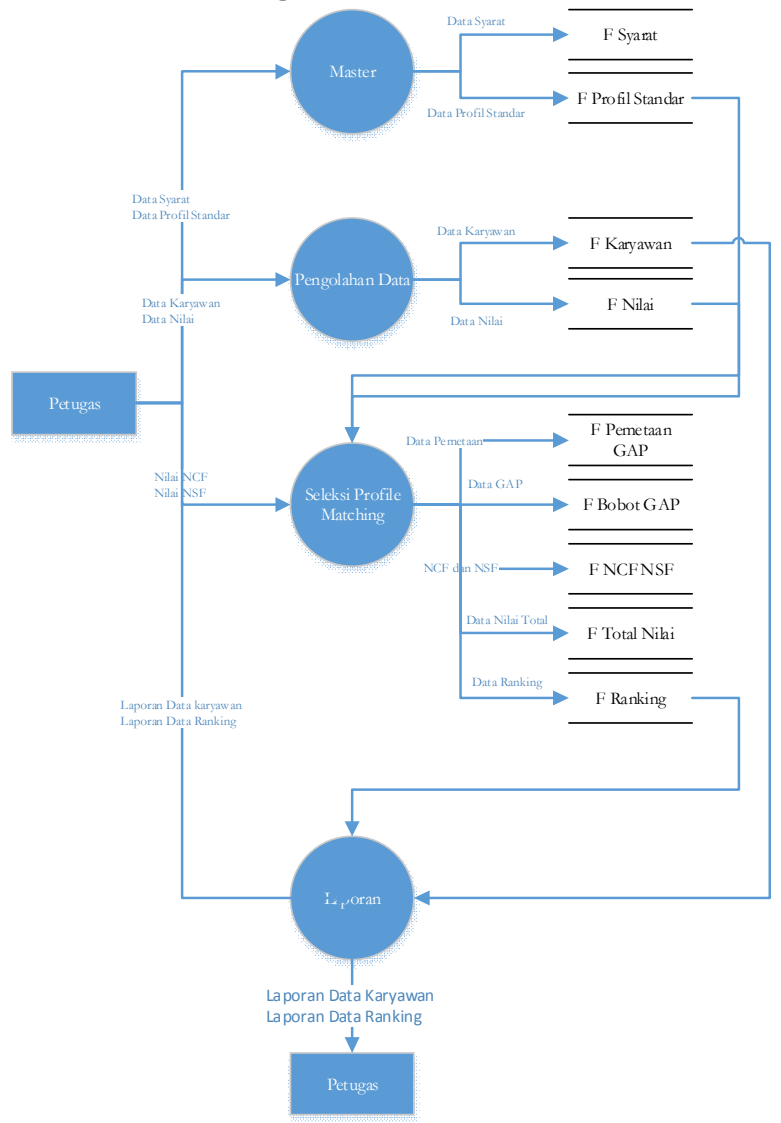

Gambar 2. DFD Level 0

\subsection{Implementasi Program}

Dari penelitian yang telah dilakukan, dihasilkan suatu sistem aplikasi pendukung keputusan mengenai pemilihan karyawan berprestasi. Setelah melakukan proses identifikasi data, analisis sistem serta perancangan aplikasi yang akan dibuat, maka berikut ini adalah beberapa tampilan form yang merupakan interaksi dari program "Decision Support System Pemilihan Karyawan Berprestasi Dengan Pendekatan Analisa Gap Profile matching Di Kantor Perwakilan Bank Indonesia Provinsi Aceh", adalah sebagai berikut:
1. Halaman Awal

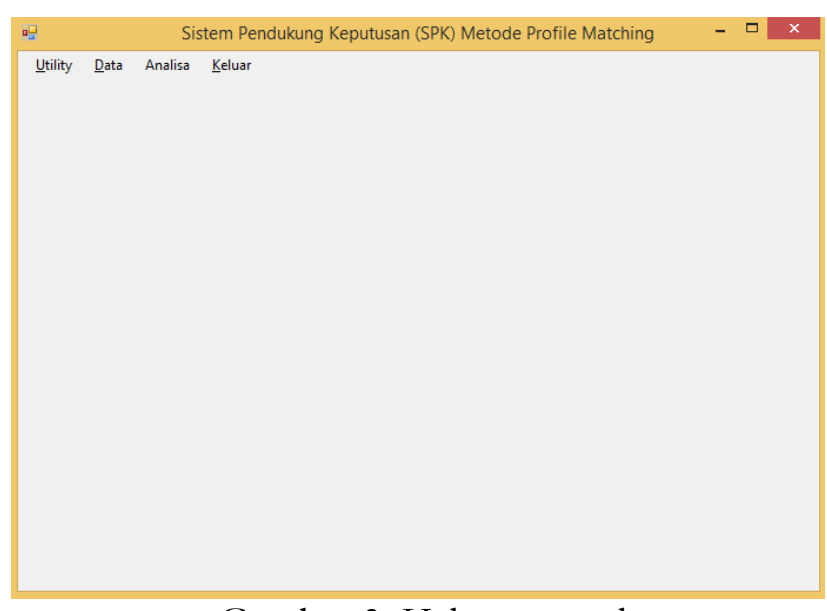

Gambar 3. Halaman awal

2. Halaman Perhitungan Core dan Secondary factor

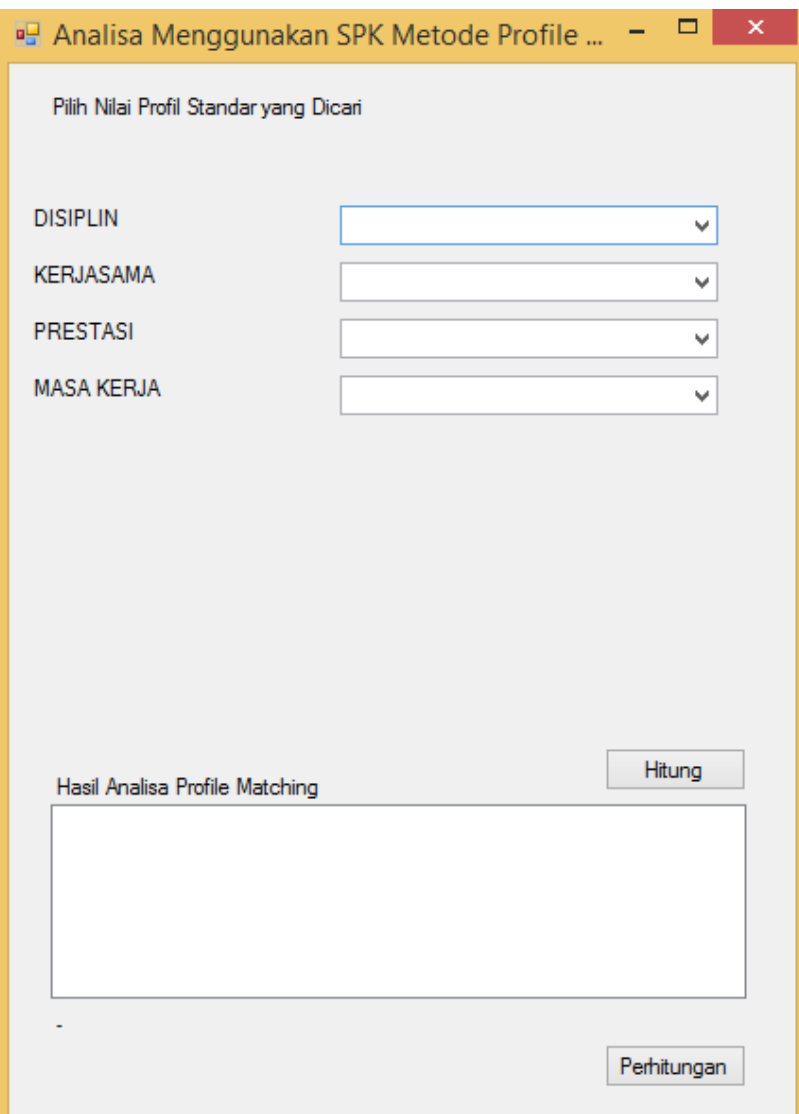

Gambar 4. Halaman Perhitungan 


\section{Halaman Nilai Total}

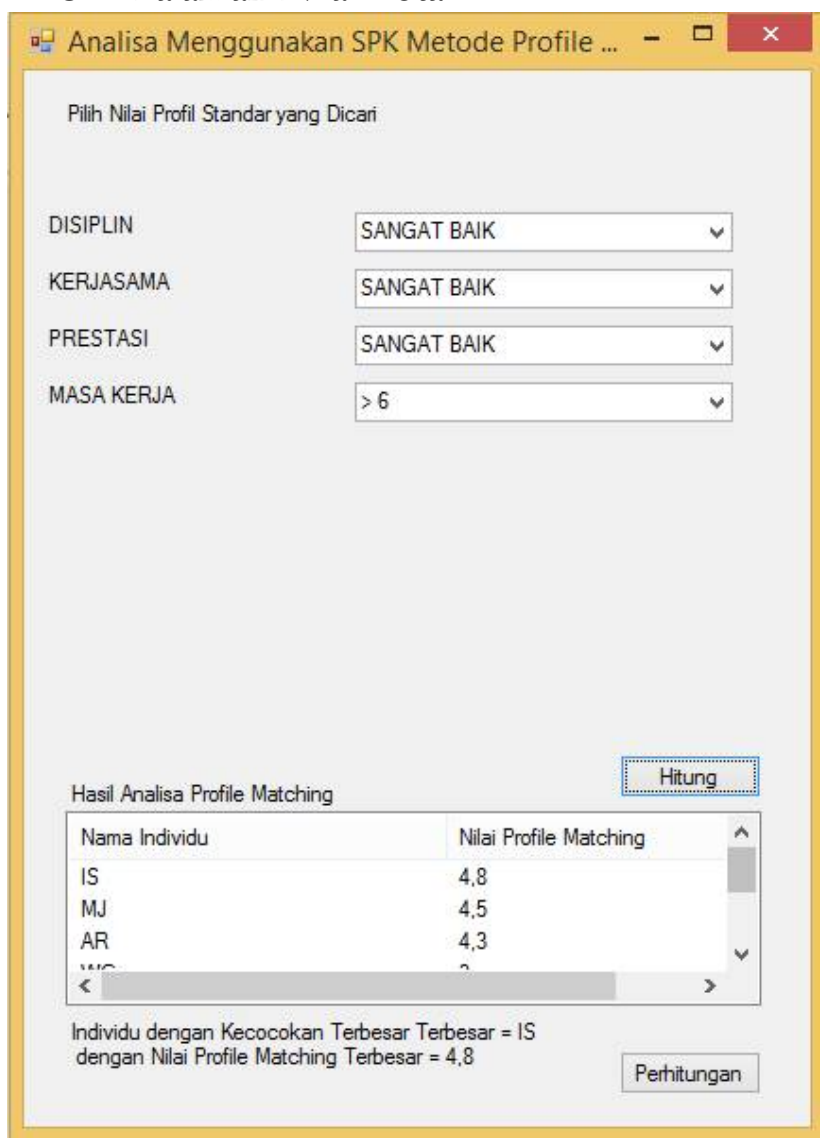

Gambar 5. Halaman Nilai Total

4. Halaman Hasil Karyawan Beprestasi

Halaman hasil karyawan berprestasi merupakan halaman akhir dari perhitungan nilai karyawan dengan kategori nilai, disiplin sangat baik, kerjasama sangat baik, prestasi sangat baik, dan masa kerja lebih dari 6 tahun. Maka, didapatkan karyawan yang memiliki nilai tertinggi seperti terlihat pada gambar 4.

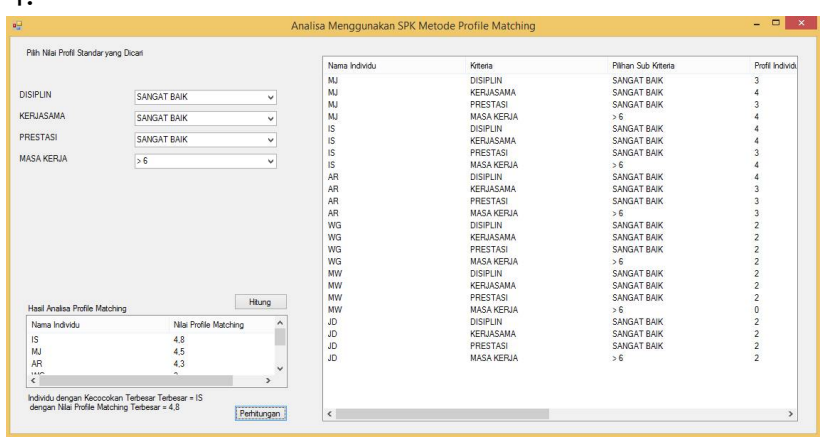

Gambar 6. Halaman Hasil Perhitungan

\section{Kesimpulan dan Saran} Secara umum, Sistem Pendukung Keputusan Kualitatif. Yogyakarta: Graha Ilmu. pemilihan karyawan berprestasi di Kantor Perwakilan Bank Indonesia Provinsi Aceh yang Kusrini, A.M., 2004. Sistem Pendukung Keputusan

dilakukan secara manual memungkinkan terjadinya kesalahan serta kelalaian di dalam menentukan karyawan yang berhak dinilai karyawan berprestasi. Sehingga membutuhkan aplikasi yang mampu menangani permasalahan tersebut secara efektif dan efisien. Sistem Pendukung Keputusan ini menampilkan rangking dari karyawan sebagai bahan pertimbangan dan alat bantu dalam pengambilan keputusan untuk menentukan karyawan berprestasi.

Proses dari penentuan rangking pemilihan karyawan berprestasi yang dilakukan dengan menggunakan metode Profile matching, dimulai dengan pemetaan gap, pembobotan kriteria, kemudian perhitungan dan pengelompokan Core dan secondary factor, perhitungan nilai total dan selanjutnya perhitungan penentuan rangking. Dengan adanya proses diatas maka dengan adanya penelitian ini peneliti merancang aplikasi sistem pendukung keputusan dengan menerapkan aplikasi sistem pendukung keputusan menggunakan metode profile matching untuk memudahkan para pengambil keputusan dalam memilih karyawan berprestasi.

\section{Daftar Pustaka}

Amalia, R., Fadlun, A. and Arivanty, K., 2009. Sistem Pendukung Keputusan untuk Menentukan Penerima Beasiswa Bank BRI Menggunakan FMADM (Studi Kasus: Karyawan Fakultas Teknologi Industri Universitas Islam Indonesia). In Seminar Nasional Aplikasi Teknologi Informasi (SNATI).

Badaruddin, B., 2017. Pengaruh Stimuli Lingkungan dan Faktor Sosial Terhadap Kecenderungan Shopaholic Emosi Positif Sebagai Variabel Mediasi pada Konsumen Suzuya Mall di Banda Aceh. Jurnal EMT KITA, 1(1).

Emzir, M. and Pd, M., 2012. Metodologi Penelitian Kualitatif Analisis data. Jakarta: Raja Grafindo.

Fahmi, I., 2017. Pengaruh Sumber-Sumber Stres Kerja Terhadap Produktivitas Kerja Karyawan PT. Bank Aceh Syariah Cabang Banda Aceh. Jurnal EMT KITA, 1(1).

Jonathan, S., 2006. Metode Penelitian Kuantitatif dan 
Evaluasi Kinerja Karyawan Untuk Promosi Jabatan.

Moleong, L.J., 2006. Metodologi Penelitian Kualitatif Edisi Revisi, Cetakan keduapuluh dua, Bandung: P'T. Remaja Rosdakarya Offset.

Putra, N., 2012. Metode Penelitian Kualitatif Pendidikan. Jakarta: Rajawali Pers.

Rizal, S., 2017. Pengaruh Kecerdasan Emosional, Perilaku Koqnitif, Kemampuan Personal dan Kompetensi Kepemimpinan Terhadap Kinerja Koperasi di Provinsi Aceh. Jurnal EMT KITA, 1(1).

Suryabrata, S., 2012. Metodologi Penelitian, Jakarta, Penerbit PT. Rajagrafindo Persada. 